\title{
PEMBERIAN LANCAU WOLIO TERHADAP PENURUNAN TEKANAN DARAH LANSIA
}

\author{
Sitti Aisyah Ansi ${ }^{1}$, Wa Ode Nesya Jeni Samrida ${ }^{2}$, \\ Politeknik Baubau, Jl. Lakarambau, Kota Baubau 93721, Indonesia ${ }^{1,2}$ \\ E-mail: ${ }^{2}$ nesyasamrida01@gmail.com
}

\begin{abstract}
The Comparative Study of the Lancau Wolio Giving to Lowering Blood Pressure of Elderly Hypertension in Katobengke Public Health Center working area in 2020. The purpose of this study was to determine the effectiveness of Lancau Wolio potion in lowering blood pressure of elderly hypertension compared to other medication. The research was a quantitative approach and a quasi-experimental that compares the results of the intervention group and the control group. The intervention group comsume the Lancau Wolio and the control group taking medical drugs (Captopril) in lowering blood pressure. The results of this study showed a decrease of systolic blood pressure on the intervention group after consuming Lancau Wolio for two weeks $(p=0.003)$ and there was no difference in diastolic blood pressure on the intervention group before and after treatment $(p=$ 0.255).In this study, Lancau Wolio was proven to be an alternative medication for hypertension which is effective in reducing systolic blood pressure by $9.32 \%$ on intervention group of elderly in Katobengke Public Center working area..

Keywords: Lancau Wolio, Hypertension, Elderly.
\end{abstract}

\begin{abstract}
ABSTRAK
Studi Komparasi Pemberian Lancau Wolio terhadap Penurunan Tekanan Darah pada Lansia dengan Hipertensi di Wilayah Kerja Puskesmas Katobengke Tahun 2020. Tujuan penelitian ini adalah untuk mengetahui efektifitas obat tradisional Lancau Wolio dalam menurunkan tekanan darah pada lansia dengan hipertensi dibandingkan obat medis lainnya. Pendekatan yang digunakan dalam penelitian ini adalah pendekatan kuantitatif. Jenis penelitian ini adalah penelitian eksperimen semu atau quasi eksperiment yang membandingkan hasil perlakuan kelompok intervensi dan kelompok kontrol, yakni kelompok intervensi yang diberikan Lancau Wolio dengan kelompok kontrol yang mengkonsumsi obat medis penurun tekanan darah (Captopril). Hasil penelitian ini menunjukan adanya penurunan tekanan darah sistolik lansia pada kelompok intervensi setelah mengkonsumsi Lancau Wolio selama dua minggu $(\mathrm{p}=0,003)$ dan tidak ada perbedaan tekanan darah diastolik pada kelompok intervensi sebelum dan setelah perlakuan $(\mathrm{p}=0,255)$. Lancau Wolio dalam penelitian ini terbukti dapat menjadi salah satu alternatif obat tradisional untuk hipertensi yang efektif menurunkan tekanan darah sistolik sebesar 9,32\% pada lansia kelompok intervensi di wilayah kerja Puskesmas Katobengke.
\end{abstract}

Kata kunci: lancau wolio; hipertensi; lansia

\section{PENDAHULUAN}

\section{Latar Belakang}

Studi pendahuluan yang dilakukan tanggal 24 Juli 2019 pada kegiatan Posyandu Lansia ditiga puskesmas di Kecamatan Katobengke Kota Bau-Bau, didapatkan penderita hipertensi sejumlah 40 pasien. Berdasarkan hasil wawancara dengan lansia penderita hipertensi, 3 pasien mengatakan bahwa mereka hanya melakukan terapi pengobatan hipertensi dengan obat medis dan belum pernah mendengar pengobatan hipertensi menggunakan obat tradisional Lancau Wolio, 5 pasien menggunakan obat tradisional Lancau Wolio , mereka percaya selain digunakan untuk perawatan masa nifas Lancau Wolio juga berkhasiat dalam menurunkan tekanan darah pada penderita hipertensi. Lancau dalam bahasa Buton mempunyai arti obat sedangkan Wolio berarti wolio. Jika diterjemahkan secara harfiah Lancau Wolio berarti obat Wolio, Lancau Wolio dibuat dengan memanfaatkan umbi, batang, dan akar dari 40 jenis tanaman, diantara beberapa tanaman yang digunakan dalam pembuatan lancau wolio, yaitu mengkudu dan buni yang dimanfaatkan batangnya, boroco yang dimanfaatkan bunganya dipercaya dapat menurunkan tekanan darah. (Anita, dkk. 2019). Kondisi pada lansia penderita hipertensi membutuhkan penanganan/terapi. Salah satu 
terapi non farmakologisnya dengan BBT (Biological Base Therapies). BBT adalah salah satu jenis terapi komplementer yang menggunakan bahan-bahan alami seperti tanaman herbal. ${ }^{(37)}$ Fenomena back to nature telah melanda masyarakat dunia sehingga tren permintaan masyarakat terhadap konsumsi pangan, minuman kesehatan dan obat dari bahan alam terus meningkat. Masyarakat cenderung menggunakan obat tradisional karena dirasa lebih aman dibandingkan obat kimia $(46,2 \%)$, selain itu alasan menggunakan obat tradisional juga karena bahan-bahannya lebih mudah didapat $(44 \%){ }^{(12)}$

\section{METODE}

Pendekatan yang digunakan dalam penelitian ini adalah pendekatan kuantitatif. Data penelitian pada pendekatan kuantitatif berupa angka-angka dan analisis menggunakan statistik. Alasan peneliti menggunakan pendekatan kuantitatif karena peneliti bermaksud untuk menghilangkan subjektifitas dalam penelitian. Jenis penelitian ini adalah penelitian Eksperimen Semu atau Quasi Eksperiment yang membandingkan penurunan tekanan darah pada pre dan post perlakuan kelompok intervensi dan kelompok kontrol, yakni kelompok intervensi adalah lansia degan hipertensi yang diberikan Lancau Wolio dengan kelompok kontrol adalah lansia dengan hipertensi yang tidak diberikan Lancau Wolio.

\section{HASIL}

Penelitian dilaksanankan di wilayah kerja Puskesmas Katobengke Kota Baubau terhadap 40 lansia dengan hipertensi yang memenuhi kriteria inklusi. Subjek dibagi kedalam dua kelompok, yaitu kelompok intervensi dan kelompok kontrol yang masing-masing terdiri atas 20 lansia.

Hasil penelitian selanjutnya disajikan dalam bentuk tabel sebagai berikut:

a. sistolik

\begin{tabular}{|c|c|c|c|}
\hline \multirow[t]{3}{*}{$\begin{array}{ll}\text { No } & \text { Kelompok } \\
\end{array}$} & \multicolumn{2}{|c|}{ Pre test } & Postutgstkan bahwa kelompok kontrok tidak \\
\hline & $\begin{array}{c}\text { TD sistolik } \\
(>120)\end{array}$ & $\begin{array}{c}\mathrm{TD} \\
\text { sistolik } \\
(\leq 120)\end{array}$ & $\begin{array}{l}\text { TDignifikardengan nilai } p 0,274(P>0,05) \text { artinya } \\
\text { sistotikak adopidrbedaan tekanan darah sistolik pada } \\
(>12 \text { loglompokzogntrol sebelum dan setelah } 2 \text { minggu. }\end{array}$ \\
\hline & $\%$ & $\%$ & \begin{tabular}{|cc} 
Xo & Kelớlanpok
\end{tabular} \\
\hline
\end{tabular}

Berdasarkan tabel 1 menunjukan bahwa pada saat pretest semua kelompok mengalami hipertensi (tekanan darah sistolik >120). Pada saat post test menunjukan hasil penurunan tekanan darah sistolik pada kelompok intervensi yaitu terdapat 2 orang (10\%) dengan tekanan darah sistolik normal $\leq 120$. Dan pada kelompok kontrol tidak menunjukan penurunan tekanan darah sistolik normal.

b. diastolik

Berdasarkan tabel 2 menunjukan bahwa pada saat pretest semua kelompok mengalami hipertensi (tekanan darah diastolik >80). Pada saat post test menunjukan tidak ada penurunan tekanan darah diastolik yang normal $\leq 80$ pada semua kelompok.

Tabel 3 menunjukan bahwa presentase penurunan rata-rata tekanan darah sistolik setelah 2 minggu intervensi atau post test paling tinggi pada kelompok intervensi yaitu dengan penurunan $9,32 \%$ dan diperoleh nilai $P=0,003<$ 0,05 artinya ada perbedaan tekanan darah sistolik sebelum intervensi dan setelah intervensi selama 2 mnggu.

Penurunan tekanan darah sistolik kelompk kontrol adalah 1,31\%, Hasil uji statistik

\begin{tabular}{llllllllll}
\hline $\mathbf{1}$ & Intervensi & 20 & 100 & 0 & & & & \\
$\mathbf{2}$ & Kontrol & 20 & 100 & 0 & & 18 & 90 & 2 & 1 \\
& & & & 20 & 100 & 0 & \\
\hline
\end{tabular}

\begin{tabular}{|c|c|c|c|c|c|c|c|c|c|}
\hline \multirow[t]{2}{*}{$\overline{\text { No }}$} & \multirow[t]{2}{*}{ Kelompok } & \multicolumn{4}{|c|}{ Pre test } & \multicolumn{4}{|c|}{ Post test } \\
\hline & & \multicolumn{2}{|c|}{$\begin{array}{c}\text { TD } \\
\text { diastolik } \\
(>80)\end{array}$} & \multicolumn{2}{|c|}{$\begin{array}{c}\mathrm{TD} \\
\text { diastolik } \\
(\leq 80)\end{array}$} & \multicolumn{2}{|c|}{$\begin{array}{c}\text { TD } \\
\text { diastoli } \\
(>80)\end{array}$} & \multicolumn{2}{|c|}{$\begin{array}{c}\text { TD } \\
\text { diastoli } \\
\mathrm{k} \\
(\leq 80)\end{array}$} \\
\hline 1 & Intervensi & $\mathrm{n}$ & $\%$ & $\mathrm{n}$ & $\%$ & $\mathrm{n}$ & $\%$ & $\mathrm{n}$ & $\%$ \\
\hline \multirow[t]{3}{*}{2} & Kontrol & 20 & 100 & 0 & 0 & 20 & 10 & & \\
\hline & & 20 & 100 & 0 & 0 & 20 & 0 & 0 & 0 \\
\hline & & & & & & & $\begin{array}{c}10 \\
0\end{array}$ & 0 & 0 \\
\hline
\end{tabular}

\begin{tabular}{llccl}
\hline No & Kelompok & pretest & Post test & \\
\hline & & Mean \pm SD & Mean \pm SD & Beda \pm SD \\
$\mathbf{1}$ & Intervensi & $166.25 \pm 4.60$ & $152.20 \pm 18.67$ & $14.05 \pm 4.10$ \\
$\mathbf{2}$ & Control & $166.55 \pm 4.73$ & $164.40 \pm 8.18$ & $2,15 \pm 1.91$ \\
\hline
\end{tabular}
.

.




\begin{tabular}{llcc}
\hline & & Mean \pm SD & Mean \pm SD \\
$\mathbf{1}$ & Intervensi & $92.00 \pm 3.18$ & $90.40 \pm 4.71$ \\
$\mathbf{2}$ & Control & $97.85 \pm 6.23$ & $93.65 \pm 5.64$ \\
\hline
\end{tabular}

Tabel 4 menunjukan bahwa persentase penurunan rata-rata tekanan darah diastolik setelah 2 minggu intervensi atau post test paling tinggi pada kelompok kontrol yaitu dengan penurunan $4,48 \%$ dan diperoleh nilai $P=0,042<$ 0,05 artinya ada perbedaan tekanan darah diastolik sebelum dan setelah 2 mnggu.

Penurunan tekanan darah diastolik kelompok intervensi adalah $1,77 \%$, Hasil uji statistik menunjukan bahwa kelompok intervensi tidak signifikan dengan nilai $p 0,255(P>0,05)$ artinya tidak ada perbedaan tekanan darah diastolik pada kelompok intevensi sebelum dan setelah 2 minggu intervensi.

Berdasarkan hasil penelitian yang telah dilakukan dapat dilihat bahwa pada saat pre-test seluruh subjek penelitian merupakan lansia penderita hipertensi dengan tekanan darah sistolik $>160 \mathrm{mmHg}$ dan tekanan darah diastolik >90 $\mathrm{mmHg}$. Kondisi tersebut menggambarkan adanya permsalahan yang serius terkait kejadian hipertensi pada lansia di wilayah kerja Puskesmas Katobengke. Penyakit darah tinggi atau hipertensi (hypertension) adalah suatu keadaan di mana seseorang mengalami peningkatan tekanan darah diatas normal, ditunjukan oleh angka systolic (bagian atas) dan angka bawah (diastolic) pada pemeriksaan tensi darah menggunakan alat pengukur tekanan darah baik berupa cuff air raksa (sphygmomanometer) ataupun alat digital lainnya.

\section{PEMBAHASAN}

Hipertensi dikenal juga sebagai the silent diseases, dimana seseorang tidak mengetahui bahwa dirinya mengalami peningkatan tekanan darah baik secara lambat maupun mendadak sebelum memeriksakan tekanan darahnya. Berbagai resiko dapat dialami oleh penderita hipertensi baik berupa kesakitan (morbiditas) maupun kematian (mortalitas). ${ }^{(4)}$ Faktor resiko hipertensi dibagi menjadi 2 golongan yaitu hipertensi yang tidak bisa diubah dan hipertensi yang dapat diubah. Hipertensi yang dapat diubah meliputi merokok, obesitas, gaya hidup yang monoton dan stres. Hipertensi yang tidak dapat dirubah meliputi usia, jenis kelamin, suku bangsa, faktor keturunan. ${ }^{(32)}$

Hipertensi pada lansia disebabkan oleh perubahan secara alamiah di dalam tubuh yang

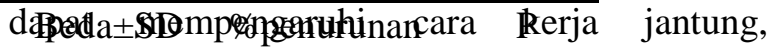
pembetulB6darah7 7lan hormon,35|5ingga terjadi

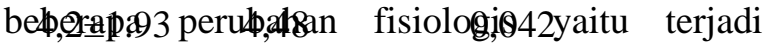
peningkatan tekanan resistensi perifer dan aktivitas simpatik serta dinding arteri akan mengalami perubahan penebalan karena adanya penumpukan zat kolagen pada lapisan otot yang meyebabkan pembuluh darah mengalami penyempitan dan kekakuan. ${ }^{(34)}$ Masalah kesehatan pada lanjut usia berawal dari kemunduran sel-sel tubuh, sehingga fungsi dan daya tahan tubuh menurun serta faktor risiko terhadap penyakitpun meningkat. ${ }^{(16)}$ Lebih dari separuh populasi lansia mempunyai tekanan darah yang lebih dari normal. Tekanan darah yang lebih dari normal akan mudah mengalami risiko penyakit kardiovaskuler. Kenaikan darah pada orang tua dipandang sebagai konsekuensi dari proses penuaan. ${ }^{(35)}$

Pada usia lanjut akan terjadi berbagai kemunduran pada organ tubuh, oleh sebab itu para lansia mudah sekali terkena penyakit seperti hipertensi. Gambaran hipertensi pada lansia hampir seluruh dari responden mengalami hipertensi sedang sebanyak 338 responden atau (96\%), sangat sedikit dari responden mengalami hipertensi ringan sebnyak 9 atau $(2,6 \%)$ dan sangat sedikit dari responden mengalami hipertensi berat sebnayak 5 atau $(1,4 \%)$ lansia. ${ }^{(7)}$

Semakin tua usia, kejadian tekanan darah tinggi (hipertensi) semakin tinggi. ${ }^{(24)} \mathrm{Hal}$ ini dikarenakan pada usia tua terjadi perubahan struktural dan fungsional pada system pembuluh darah perifer yang bertanggung jawab pada perubahan tekanan darah yang terjadi pada usia lanjut. Perubahan-perubahan pada lansia di negara-negara maju yaitu perubahan pada system kardiovaskuler yang merupakan penyakit utama yang memakan korban karena akan berdampak pada penyakit lain seperti hipertensi, penyakit jantung koroner, jantung pulmonik, kardiomiopati, stroke, gagal ginjal. ${ }^{(9)}$

Hipertensi bisa terjadi pada semua usia, tetapi semakin bertambah usia seseorang maka resiko terkena hipertensi semakin meningkat. Penyebab hipertensi pada orang dengan lanjut usia adalah terjadinya perubahan-perubahan pada, elastisitas dinding aorta menurun, katub jantung menebal dan menjadi kaku, kemampuan jantung memompa darah menurun $1 \%$ setiap tahun sesudah berumur 20 tahun kemampuan jantung memompa darah menurun menyebabkan menurunnya kontraksi dan volumenya, kehilangan elastisitas pembuluh darah. Hal ini terjadi karena kurangnya efektifitas pembuluh 
darah perifer untuk oksigenasi, meningkatnya resistensi pembuluh darah perifer. ${ }^{(38)}$

Pada penelitian ini terlihat bahwa lansia yang menderita hipertensi sebagian besar $(65 \%)$ atau sejumlah 26 responden berjenis kelamin perempuan dan sebanyak 14 responden berjenis kelamin laki-laki. Hal ini sesuai dengan penelitian yang menemukan bahwa jumlah penderita hipertensi perempuan lebih banyak dari pada lakilaki. Ini dikarenakan perempuan mengalami menopause, yang pada kondisi tersebut terjadi perubahan hormonal, yaitu terjadi penurunan perbandingan estrogen dan androgen yang menyebabkan peningkatan pelepasan renin, sehingga dapat memicu peningkatan tekanan darah. (Sundu, Reksi, dkk, 2018). Penelitian lain juga menyebutkan bahwa, dari semua lansia yang terkena hipertensi kebanyakan semuanya berjenis kelamin perempuan. Laki-laki memiliki peluang lebih besar untuk mengembangkan tekanan darah tinggi dari pada wanita. Akan tetapi wanita juga berada pada risiko yang tinggi pula. Pada usia 4564 , baik pria maupun wanita memiliki tingkat risiko yang sama. Jenis kelamin sangat erat kaitannya terhadap terjadinya hipertensi di mana pada laki-laki penyakit hipertensi lebih tinggi sering terjadi pada masa muda sedangkan pada wanita lebih tinggi setelah umur 55 tahun, ketika seorang wanita mengalami menopause. (Muti, T.R, 2017) Hasil penelitian ini menunjukkan penurunan tekanan darah sistolik pada kelompok intervensi yaitu terdapat 2 orang (10\%) dengan tekanan darah sistolik normal $\leq 120$. Dan pada kelompok kontrol tidak menunjukan penurunan tekanan darah sistolik normal. Pada saat post test menunjukan tidak ada penurunan tekanan darah diastolik yang normal $\leq 80$ pada semua kelompok. Tingginya Hipertensi sejalan dengan bertambahnya umur, disebabkan oleh perubahan struktur pada pembuluh darah besar, sehingga lumen menjadi sempit dan dinding pembuluh darah menjadi lebih kaku, sebagai akibat adalah meningkatnya tekanan darah sistolik. Dengan meningkatnya umur didapatkan kenaikan tekanan darah diastol rata-rata walaupun tidak begitu nyata juga terjadi kenaikan angka prevalensi Hipertensi tiap kenaikan kelompok dekade umur. ${ }^{(36)}$ Sejalan dengan bertambahnya usia, hampir setiap orang mengalami kenaikan tekanan darah, tekanan sistolik terus meningkat sampai usia 80 tahun dan tekanan diastolik terus meningkat sampai usia 55-60 tahun, kemudian berkurang secara perlahan atau bahkan menurun drastis.

Penelitian ini menunjukan adanya penurunan tekanan darah sistolik lansia pada kelompok intervensi setelah mengkonsumsi Lancau Wolio selama dua minggu $(\mathrm{p}=0,003)$ dan tidak ada perbedaan tekanan darah diastolik pada kelompok intervensi sebelum dan setelah perlakuan $(\mathrm{p}=0,255)$. Hipertensi pada lansia disebut dengan hipertensi sistolik dimana dalam hal ini semakin bertambahnya usia seseorang akan mengalami kenaikan tekanan darah karena pada usia lanjut terjadi penebalan dan kekakuan pada dinding arteri yang disebabkan oleh arterosklerosis sehingga jantung harus bekerja secara keras untuk memompa darah dengan keadaan pembuluh darah yang mengalami penyempitan, maka hal ini akan menyebabkan tekanan darah menjadi naik. Tekanan darah sistolik akan mengalami peningkatan sampai usia 80 tahun sedangkan tekanan darah diastolik akan mengalami peningkatan samapi berusia 55-60 tahun.

Lancau Wolio dalam penelitian ini terbukti dapat menjadi salah satu alternatif obat tradisional untuk hipertensi yang efektif menurunkan tekanan darah sistolik sebesar 9,32\% pada lansia kelompok intervensi di wilayah kerja Puskesmas Katobengke. Lancau Wolio dibuat dengan memanfaatkan umbi, batang, dan akar dari 40 jenis tanaman. Diantara beberapa tanaman yang digunakan dalam pembuatan lancau wolio, yaitu diantara beberapa tanaman yang digunakan dalam pembuatan lancau wolio, yaitu mengkudu dan buni yang dimanfaatkan batangnya, boroco yang dimanfaatkan bunganya dipercaya dapat menurunkan tekanan darah. (Anita, dkk. 2019)

Buah mengkudu banyak mengandung zat kimia yang sangat berguna bagi tubuh diantaranya adalah senyawa Terpenoid, Zat asam (askorbat, kaproat, karpitat), Zat antibakteri (Acubin, L.asperuloside, alizarin, antraquinon), Nutrisi (karbohidrat, protein, vitamin, mineral esensial), Zat anti kanker (damnacanthal), Zat Scopoletin (antihipertensi). Kandungan buah mengkudu yang dapat menurunkan tekanan darah adalah Scopoletin. Zat Scopoletin dalam buah mengkudu ditemukan pada tahun 1993 oleh para peneliti di Universitas Hawaii. Scopoletin berfungsi memperlebar saluran pembuluh darah yang 
mengalami penyempitan serta melancarkan peredaran darah. Kandungan scopoletin buah mengkudu dalam 1 gram adalah sebesar 290,02 ppm. Scopoletin dapat menurunkan tekanan darah dengan cara menurunkan tahanan atau resistensi perifer. Besarnya tahanan perifer bergantung pada kontraktilitas otot polos pembuluh darah. Kontraktilitas otot polos pembuluh darah dipengaruhi oleh fungsi endotel pembuluh darah, karena pada endotel disintesis dan disekresi berbagai bahan vasokonstriktor dan vasodilator. Kandungan bahan aktif scopoletin dalam mengkudu memiliki fungsi dalam menormalkan tekanan darah dengan adanya efek spasmolitik yaitu efek yang mempunyai kemampuan serupa dengan cara kerja obat antihipertensi. Efek spasmolitik ditandai dengan terjadinya pelebaran pembuluh darah (vasodilatasi) akibat relaksasi otot polos. Otot polos pembuluh darah diatur oleh sistem syaraf simpatis melalui pengeluaran neurotransmiter noradrenalin di ujung syaraf simpatis pada dinding pembuluh darah sehingga otot polos direlaksasi oleh zat scopoletin yang berfungsi sebagai vasodilator.

Perlu adanya penanganan dan upaya pencegahan penyakit hipertensi pada lansia, diantaranya dengan memberikan edukasi tentang pola hidup sehat agar terhindar dari hipertensi dan segala komplikasi yang dapat menyertainya.

\section{KESIMPULAN}

Hipertensi pada lansia disebabkan oleh perubahan secara alamiah di dalam tubuh yang dapat mempengaruhi cara kerja jantung, pembuluh darah dan hormon,sehingga terjadi beberapa perubahan fisiologis yaitu terjadi peningkatan tekanan resistensi perifer dan aktivitas simpatik serta dinding arteri akan mengalami perubahan penebalan karena adanya penumpukan zat kolagen pada lapisan otot yang meyebabkan pembuluh darah mengalami penyempitan dan kekakuan. Penelitian ini menunjukan adanya penurunan tekanan darah sistolik lansia pada kelompok intervensi setelah mengkonsumsi Lancau Wolio selama dua minggu $(\mathrm{p}=0,003)$ dan tidak ada perbedaan tekanan darah diastolik pada kelompok intervensi sebelum dan setelah perlakuan $(p=0,255)$. Lancau Wolio dalam penelitian ini terbukti dapat menjadi salah satu alternatif obat tradisional untuk hipertensi yang efektif menurunkan tekanan darah sistolik sebesar 9,32\% pada lansia kelompok intervensi di wilayah kerja Puskesmas Katobengke.

\section{DAFTAR PUSTAKA}

1. Adwiyah, Rabiatul. 2017. Analisis kadar saponin ekstrak metanol kulit batang kemiri (aleurites moluccana (1.)Willd) dengan metode gravimetri. Skipsi Strata I. Fakultas Kedokteran dan Ilmu Kesehatan Masyarakat. Universitas Islam Negeri Aladdin Makassar, Makassar.

2. Afreni, M., Amaliani, T., Rizaldi, Rahanto, S., 2014, Kesembuhan Mulia Mamoh, Etnik Aceh Kabupaten Aceh Barat, Buku Seri Etnografi Kesehatan, Jakarta, LPB.

3. Agoes, Azwar, 2011, Tanaman Obat Indonesia, Salemba Medika, Jakarta.

4. Agustina, Sri, Sari, Siska Mayang \& Savita, Reni (2014). Faktor-Faktor yang Berhubungan dengan Hipertensi Pada Lansia di Atas Umur 65 Tahun. Jurnal Kesehatan Komunitas, 2(4), 180-186.

5. Aksara, Riska, 2013. Identifikasi Senyawa Alkaloid Dari Ekstrak Metanol Kulit Batang Mangga (Mangifera Indica L.), 8(1), hal. 510-515.

6. Anita, Ernawati Sri (2020). Efektifitas Pemberian Obat Tradisional Lancau Wolio Terhadap Involusi Uterus dan Estetika Kecantikan Pada Ibu Nifas Di Kota Baubau, Journal Of HealthCare Technology and Medicine, Vol 6 (2) hal. 666-677.

7. B2P2TOOT, 2017, Riset Khusus Eksplorasi Pengetahuan Lokal Etnomedisin Dan Tumbuhan Obat Berbasis Komunitas Di Indonesia, Jakarta, Kementrian Kesehatan Republik Indonesia.

8. C. Putri, Nyayu Nina \& Meriyani, Intan. (2020). Gambaran Tekanan Darah Pada Lansia Hipertensi Di Wilayah Kerja Puskesmas Kademangan Kabupaten Cianjur. Jurnal Keperawatan Komprehensif, 6(1), 64-49.

9. Dewi, Sofia (2014) Buku Ajar Keperawatan Gerontik. Yogyakarta: Deepublish.

10. Fatmah. (2010). Gizi lanjut usia. Jakarta: Erlangga. 
11. Fitri, Nur Lailatul, 2016, pengaruh ekstrak buah ciplukan (physalis angulata l.) Terhadap kadar spgt dan sogt mencit putih jantan (Mus musculus). Jurnal Pendidikan Biologi Indonesia, 2 (2), hal. 180-187.

12. Hendri Wasito, 2011. Obat Tradisional Kekayaan Indonesia. Yogyakarta : Graha Ilmu.

13. Hidayat, Rina Pratiwi, 2014. Potensi Kapuk Randu (Ceiba Petandra Gaertn) Dalam Penyediaan Obat Herbal. E-Journal Widya Kesehatan dan Lingkungan, 1 (1), hal. 53-60.

14. Ismarani, diah, dkk, 2014. Formulasi Gel Pacar Air (Impatiens balsamina Linn.) terhadapPropionibacterium acnes dan Staphylococcus epidermis. Jurnal Medical International

15. Karahap, Angga D, 2016. Uji efek antibakteri ekstrak batang akar kuning (arcangelisia flavamerr.) Terhadap bakteri sthaphylococcus aureus dan escherichia coli. Jurnal eBiomedik, 4 (1), Hal 661-670.

16. Kartika, Rudi, 2016. Pengaruh pemberian ekstrak etanol daun kecapi (sandoricum koetjape (burm.f.) Merr.) Terhadap penurunan kadar kolesterol total pada mencit jantan (mus musculus). Jurnal Kimia Mulawarman, 13 (2), hal. 64-67.

17. Kementerian Kesehatan RI. 2015.Riset Kesehatan Dasar (RISKESDAS). Jakarta: Badan Litbang Kemenkes RI

18. Latief, Abdul, 2013, Obat Tradisional, Jakarta : EGC

19. Listiawati, Yeni, 2010. Uji efek antipiretik ekstrak etanol daun legundi (vitex trifolia linn) pada kelinci yang diinduksi vaksin dpt-hb. Skripsi Strata I. Fakultas Farmasi, Universitas Muhammadiyah Surakarta, Surakarta

20. Lungu, Marten, 2010. Pemanfaatan Rotan Oleh Suku Dayak Merap Di Desa Gong Solok Kecamatan Malinau Selatan Kabupaten Malinau. Skipsi Strata I . Jurusan Manajemen Hutan. Politeknik Pertanian Negeri Samarinda, Samarinda.
21. Lusiana, Kesi, dkk, 2013, aktivitas antibakteri dan kandungan fitokimia ekstrak daun waru lengis (hisbiscus tillaceus l.) Sebagai bahan dasar pembuatan sampo. Jurnal Biokimia, 5 (5), hal. 631-638

22. Murni, dkk, 2014. Efektivitas ekstrak etanol daun ketepeng (cassia alata 1.) Dan ketepeng kecil (cassia tora 1.) Terhadap plasmodium falciparum secara in vitro. Jurnal Balaba, 10 (2), hal.83-88

23. Muti, T.R, 2017. Pengaruh Parutan Kunyit Pada Penurunan Hiperteni Pada Lansia di Kelurahan Berkoh Kecamatan Purwekerto Selatan Kabupaten Banyumas Tahun 2017.

24. Notoatmodjo, 2013, Promosi Kesehatan Dan Ilmu Perilaku, Jakarta: Rineka Cipta.

25. Novian A, 2013. Kepatuhan Diet Pasien Hipertensi. Jurnal keehatan masyarakat Volume 1, Nomor 9.

26. Pelealu, Delano, dkk, 2015. Pengaruh Jamu Dengan Tribulus Terrestris Terhadap Kualitas Sperma Tikus Wistar Jantan (Rattus norvegicus). Jurnal e-Biomedik (eBm),3 (2), Hal. 661665.

27. Pratama, Aditya Bagus, Firzatullah Dwiko Ramadhan, 2013, Khasiat Tanaman Obat Herbal, Surabaya, Pustaka Media.

28. Pratiwi, Ratih Dyah, 2016. Uji aktivitas anti bakteri gel sariawan dari ekstrak daun saga (abrus precatorius linn.) Terhadap bakteri staphyloccocus aureus. Jurnal Ilmiah Manuntung, 2 (2), hal. 239-247.

29. Puspita, Sari Endah, dkk, 2009. Uji sitoksisitas ekstrak metanol buah buni (antidesma bunius (l.) Spreng) terhadap sel hela. Jurnal Ilmu Dasar, 10 (2), hal. 181185.

30. Rahimsyah, AR., 2012, Penyembuhan Alami Dengan Herbal Dan Pijat Refleksi, Surabaya, Dua Media.

31. Rahmi, dkk, 2011. Potency Of Java Talinum, Paniculatun Gaertn). Jurnal Kesehatan, 11 (1), hal 235-240. 
32. Ratna Dewi Pudiastuti, 2013, Penyakit Penyakit Mematikan, Nuha Medika, Yogyakarta

33. Rusdi., \& Isnawati, N. (2009). Pedoman Hidup Sehat. Yogyakarta: Power Books.

34. Sabuding, Miss Amanee, 2018. Ujiaktivitas antidiabetes ekstrak etanol bunga kertas (bougainvillea spectabilis wild.) Pada tikus wistar yang diinduksi aloksan. Skripsi Strata I. Program Studi Farmasi. Universitas Muhammadiyah Surakarta, Surakarta

35. Safitri, Arum Reyhan \& Ismawati, Rita. (2018). Efektifitas Teh Buah Mengkudu Dalam Menurunkan Tekanan Darah Lansia Dengan Hipertensi. Amerta Nutrition. 2(2), 163-171.

36. Santoso, Djoko. 2010. Membonsai Hipertensi. Surabaya : Jaring Pena.

37. Sartik, S., Tjekyan, R. S., \& Zulkarnain, M. (2017). Risk Factors And The Incidence Of Hipertension In Palembang. Jurnal Ilmu Kesehatan Masyarakat, 8(3), 180-191.

38. Smart, Aqila (2015) Sehat \& Awet Muda dengan MetodeTradisional. Yogyakarta : Kata Hati.

39. Smeltzer, Suzanne, C. 2007.Buku Ajar Keperawatan Medikal Bedah Brunner \& Suddarth. Jakarta : EGC.

Sulistiawati, Ni Made, 2015. Ekstrak Kulit Batang Kusambi, Schleiscera olesa (oles), Jurnal kesehatan, Politeknik Baubau, Baubau

Susilowati, Bau andi, 2014, pengaruh getah tanaman jarak pagar (jathropa curcas 1.) Terhadap daya hambat bakteri (staphyloccus), Jurnal Kesehatan, Politeknik Baubau, Baubau

Sundu, Reksi, dkk, 2018. Uji Aktivitas Antibakteri Ekstrak Etanol Umbi Paku Atai Merah

(Angiopteris ferox Copel) TERHADAP Propionibacterium acnes. Jurnal Medical Sains, 2 (2), hal. 7582

Suparni, Ari Wulandari, 2013, Herbal Nusantara, Yogyakarta : Andi Publisher

Triyanto, E. Pelayanan Keperawatan Bagi Penderita Hipertensi Secara Terpadu. (Graha Ilmu, 2014).
Vitria, Vanis, 2016. Pengaruh Ekstrak Ranting Dan Daun Tumbuhan Patah Tulang (Euphorbia Tirucalli) Terhadap Mortalitas Ulat Grayak (Sdoptera Litura) Instar Ii Secara In Vitro Sebagai Bahan Ajar Biologi. Skripsi Strata I. Program Studi Pendidikan Biologi. Universitas Muhammadiyah Malang, Malang.

Waluyo, Joko, 2014. Perbedaan daya hambat ekstrak daun kepuh (sterculia foetida l.) Dan jarak pagar (jatropha curcas l.) Terhadap pertumbuhan propionibacterium acne. Junal Saintifika, 16 (1), hal. 10-17.

Walyani, E, S., Wahyuni, A., 2015, Asuhan Kebidanan Kegawatan Maternal Dan Neonatal, Pustaka baru pres.

Wirastuty, Resky Yalastri, 2016. Uji Efektifitas Gel Ekstrak Etanol Kulit Batang Kayu Jawa (Lannea Coromandelica) Pada Kelinci (Oryctolagus Cuniculus) Sebagai Obat Penyembuhan Luka Bakar, 1 (1), hal. 32-35. 